http://dx.doi.org/10.18778/0208-6050.95.06

MICHAŁ SIERBA

(UNIWERSYTET ŁÓDZKI)

\title{
Tykociński przytułek wojskowy w XVII w. - funkcje społeczne i militarne
}

Dziś Tykocin jest małym miasteczkiem położonym w powiecie białostockim w województwie podlaskim. W czasach I Rzeczypospolitej Tykocin był stolicą powiatu należącego do ziemi bielskiej województwa podlaskiego. Od 1542 do 1661 r. miasto było królewszczyzną, później przeszło w ręce Stefana Czarnieckiego i rodu Branickich herbu Gryf. Artykuł ten będzie dotyczył jednego z tykocińskich budynków, który powstał w pierwszej połowie XVII w. i zachował się do dziś - alumnatu żołnierskiego.

Alumnat ${ }^{1}$ jest zwyczajową nazwą tykocińskiego przytułku dla weteranów. Powstanie alumnatu wiąże się z osobą Krzysztofa Wiesiołowskiego. Był on synem Piotra Wiesiołowskiego i Zofii Lubomirskiej. Tak jak jego ojciec pełnił wiele urzędów, m.in. podstolego (od 1600 r.), stolnika (od 1604 r.), krajczego (od 1620 r.), marszałka nadwornego (od 1623 r.), by zakończyć swą karierę polityczną, jak ojciec, jako marszałek wielki litewski. Oprócz tego był starostą i leśniczym w licznych królewszczyznach ${ }^{2}$. Wśród starostw przez niego dzierżonych znajdowało się także starostwo tykocińskie, które przed $1616 \mathrm{r}$. scedował na niego Piotr Wiesiołowski ${ }^{3}$. Krzysztof Wiesiołowski był także fundatorem wielu budowli ${ }^{4}$. Był również odpowiedzialny za przebudowę fortyfikacji zamku

\footnotetext{
${ }^{1}$ Słowo ,alumnat” jest błędnie użyte względem tykocińskiego przytułku dla weteranów, ale nazwa ta odnotowywana była w źródłach dotyczących miasta i utarła się w tradycji. Według Z. Glogera w dobie staropolskiej ,alumnat” oznaczał „zakłady, w których uczniowie, alumni, otrzymywali bezpłatnie, kosztem biskupów, z funduszów kościelnych lub z zapisów prywatnych stół, mieszkanie i naukę". Z. Glog e r, Encyklopedia staropolska ilustrowana, t. I, Warszawa 1900, s. 42.

${ }^{2}$ Narodowy Instytut Dziedzictwa w Warszawie, Teki Glinki [dalej: TG] 278, s. 173; Urzędnicy centralni i dygnitarze Wielskiego Księstwa Litewskiego XIV-XVIII w. Spisy, oprac. H. Lulewicz, A. Rachuba, Kórnik 1994, s. 59, 74, 77, 165, 188.

${ }^{3}$ TG 62, k. 67v, 82. W lustracji z 1616 r. zapisano, że starostą był Krzysztof Wiesiołowski. Archiwum Główne Akt Dawnych [dalej: AGAD], Archiwum Skarbu Koronnego [dalej: ASK], oddział XLVI, nr 149, k. 99.

${ }^{4}$ Między innymi: klasztoru św. Brygidy w Grodnie; kościołów w Dąbrowie, Chodorowie, Łunnie, Kwasowie, Dolistowie, Bartkowie, Wielkiej Krzemnicy; obdarował 20 kościołów w 14
} 
w Tykocinie, w którym mieszkał do $1621 \mathrm{r}$. Był żonaty z Aleksandrą Marianną z Sobieskich. Zmarł bezpotomnie 19 kwietnia 1637 r. $^{5}$

Krzysztof Wiesiołowski był także fundatorem tykocińskiego alumnatu. W 1633 r. dokonał zapisu fundacyjnego, który został zaakceptowany przez sejm koronacyjny 15 lutego tego roku'. Mówił on o tym, że na utrzymanie szpitala żołnierskiego Wiesiołowski przeznaczył dobra Dolistowo, „żeby pomienione dobra, ani in toto, ani in parte, na żadną inszą rzecz przez nas, ani potomki nasze, obrócone nie były"7. Był to trzeci tego typu budynek w Rzeczpospolitej, jako pierwszy założony przez osobę prywatną ${ }^{8}$. Pełnił swą funkcję najdłużej, bo z przerwami aż do $1915 \mathrm{r}$.

W 1635 r. Wiesiołowski sporządził regulamin alumnatu. Według niego w szpitalu żołnierskim miało mieszkać 12 weteranów, każdy z nich w osobnym pomieszczeniu. Po śmierci fundatora hetman wielki koronny miał prawo wyboru mieszkańców alumnatu, jednak pojawiały się pewne ograniczenia. Pensjonariusz musiał być szlachcicem wyznania rzymskokatolickiego, zasłużonym dla ojczyzny. Musiał także nie mieć środków na swoje utrzymanie i możliwości ich zdobycia ze względu na odniesione rany w obronie ojczyzny bądź ze względu na wiek. W regulaminie Wiesiołowski zapisał również, że pierwszeństwo do zamieszkania $\mathrm{w}$ alumnacie mają członkowie jego rodziny, jeśli zaistniałaby taka potrzeba. Każdy z pensjonariuszy miał co roku otrzymywać 200 zł na utrzymanie: w czterech ratach po $50 \mathrm{zł}$ na każdy kwartał. Mieszkańcy alumnatu powinni żyć ze sobą w zgodzie, „a w życiu i obyczajach niech przystojność granic nie przystępują" ". Jeśli któryś z pensjonariuszy łamałby te zasady współistnienia, hetman wielki koronny miał prawo usunąć go z alumnatu i na jego miejsce umieścić kogoś innego. Władzę nad mieszkańcami, poza królem i hetmanem wielkim koronnym, mieli także bezpośrednio starości tykocińscy, którzy mieli zarządzać dochodami z dóbr Dolistowo i rozdzielać pieniądze pensjonariuszom ${ }^{10}$. Jeśli dobra

miejscowościach, a także uposażył lub obdarował 10 szpitali. TG 62, s. 44; TG 72, s. 49. Vide: W. W r ó b e 1, Fundacje kościelne białostockiej linii rodu Wiesiołowskich w XVI $i$ XVII w., „Prace Naukowe Akademii im. Jana Długosza w Częstochowie", Zeszyty Historyczne 2009, z. 10, s. 165-215.

${ }^{5}$ TG 62, k. 51v; TG 72, s. 9, 26. Po śmierci żony Wiesiołowskiego większość z dóbr osobistych po niej trafiło do jej siostrzeńca Hieronima Radziejowskiego. TG 72, s. 9.

6 AGAD, Zbiór Ignacego Kapicy Milewskiego „Kapicjana” [dalej: Kapicjana], sygn. 61, s. $577-633$.

${ }^{7}$ Volumina Legum, t. III, Petersburg 1859, s. 385-386.

${ }^{8}$ Wcześniej dwa przytułki dla weteranów (w Warszawie i Trechtymirowie) założył król Stefan Batory. P.M. Gartki ew ic z, Tykocin. Alumnat wojskowy, Narodowy Instytut Dziedzictwa w Białymstoku, mps 1959, s. 7.

${ }^{9}$ M. B a l iń s k i, T. L i p i ń s k i, Starożytna Polska pod względem historycznym, jeograficznym i statystycznym opisana, t. II, cz. 2, Warszawa 1845, s. 1322.

${ }^{10} \mathrm{Na}$ przykład starosta tykociński Wojciech Wessel z żoną Marianną Potocką (za zgodą króla) w 1655 r. przekazali w dożywocie trzy puste włóki w Dolistowie Wawrzyńcowi Grabi. Był on 
te przyniosłyby większe dochody, starosta miał je przeznaczyć m.in. na utrzymanie alumnatu (czyli np. remonty). Dobra Dolistowo miały nigdy nie wejść do domeny monarszej i nie miały być obciążane żadnymi ciężarami na rzecz państwa. Dnia 27 marca 1638 r. Władysław IV zatwierdził ten regulamin ${ }^{11}$.

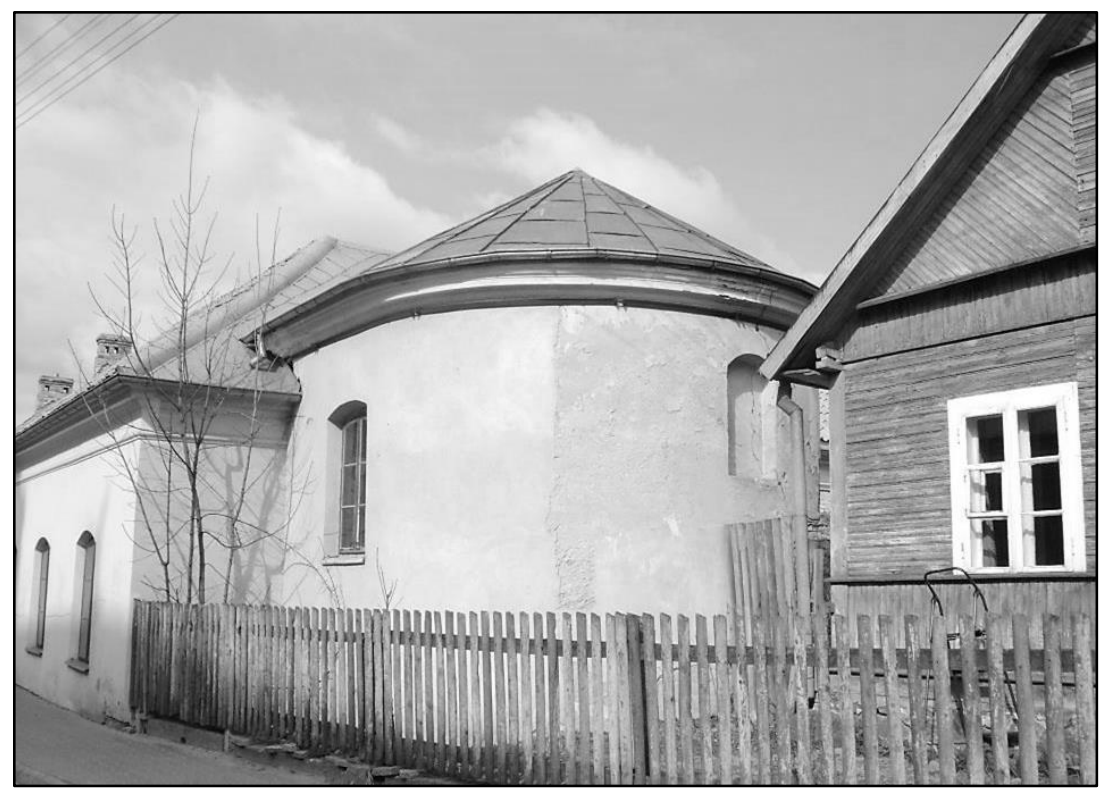

1. Absyda alumnacka, fot. autor

Autorem projektu budynku szpitala żołnierskiego najprawdopodobniej był Krzysztof Wiesiołowski ${ }^{12}$. Prace budowlane rozpoczęto pod koniec 1633 lub na początku 1634 r. $^{13}$ Mimo jego śmierci w 1637 r. wznoszenie alumnatu kontynuowano $^{14}$. Zajęła się tym żona fundatora - Aleksandra z Sobieskich. Ze spisanego 29 kwietnia 1645 r. testamentu dowiadujemy się, że za życia Krzysztofa „,tylko fundamenta wywiedzione były"15. Aleksandra Wiesiołowska także nie

wolny od wszelkich powinności poza opłatą 6 zł od włóki na rzecz alumnatu. AGAD, Kapicjana, sygn. 61 , s. 31-57.

${ }^{11}$ M. B a 1 i ń s k i, T. L i p iń s k i, op. cit., s. 1321-1324; B. T y k i e 1, Kilka uwag historyczno-statystycznych o Guberni Augustowskiej, cz. 4, „Biblioteka Warszawska” 1857, t. IV, s. 612-618.

12 TG 278, s. 178; S. W i c h e r, Alumnat wojskowy w Tykocinie, „Biuletyn Konserwatorski Województwa Podlaskiego" 2003, z. 8-9, s. 19, 41.

${ }^{13}$ P.M. G a r t k i e w i c z, Alumnat wojskowy w Tykocinie, ,Kwartalnik Architektury i Urbanistyki" 1962, t. VII, z. 2, s. 126.

${ }^{14}$ Przemysław M. Gartkiewicz sądzi, że prace ukończono w 1636 r., ale późniejsze dokumenty wskazują, że nie mogło to już wtedy nastąpić. Ibidem.

${ }^{15}$ TG 278, s. 15 . 
doprowadziła do końca budowy alumnatu. W testamencie swą główną spadkobierczynią czyniła klasztor brygidek w Grodnie i upoważniła swą siostrę Annę, ksienię tego klasztoru, do zarządzania funduszami alumnackimi, ale również do wykończenia wnętrza budynku ${ }^{16}$. Prace zostały zakończone do $1647 \mathrm{r}$. Wskazuje na to m.in. skierowanie do alumnatu 1 czerwca 1647 r. Marcina Piotrowskiego przez nowego starostę tykocińskiego Wojciecha Wessela ${ }^{17}$.

Alumnat został usytuowany w północno-wschodnim rogu starego rynku tykocińskiego, zaraz obok przeprawy przez rzekę Narew. Wcześniej stał tam tzw. dworzec stary, który odnotowuje jeszcze inwentarz z $1571 \mathrm{r}^{18}$ Alumnat to parterowy, murowany $\mathrm{z}$ cegły, tynkowany zaprawą wapienną budynek na planie zbliżonym do kwadratu ${ }^{19}$. Położony jest na parceli o wymiarach $50 \times 45 \mathrm{~m}$. Zewnętrzne wymiary budynku to $38 \times 34 \mathrm{~m}$. Jest to budowla czteroskrzydłowa, zamknięta wokół wewnętrznego dziedzińca. W południowej części wschodniego skrzydła znajduje się półokrągła absyda. Alumnat przykryty był dachem dwuspadowym, krytym dachówką, tylko absyda była kryta blachą. Dach był pierwotnie wyższy niż dziś. W związku ze swoim położeniem przy przeprawie i funkcjami, jakie budynek miał pełnić w czasie wojny, miał cechy budowli obronnych. Od strony północnej istniały dwie baszty w narożach. Wspominają o nich inwentarze z 1698 i $1701 \mathrm{r}$.: „,W dwóch rogach bakszty dwie”20. W południowo-wschodniej części budynku mieściła się kaplica ${ }^{21}$. Pod nią znajdowała się krypta, gdzie chowano zmarłych pensjonariuszy. Prezbiterium kaplicy było we wspomnianej absydzie. Ściany budynku były pokryte skromną, wczesnobarokową dekoracją w postaci „profilowanych obramień okiennych i podobnego gzymsu” ${ }^{\text {,2 }}$. Sebastian Wicher określił styl pierwotnego budynku jako tzw. styl wazowski. Nad bramą wjazdową umieszczono tablicę erekcyjną. Dwanaście pokoi mieszkalnych było przesklepionych, a pomieszczenia użytkowe i pomocnicze najprawdopodobniej przykryto drewnianymi stropami belkowymi. Pierwotnie układ wewnętrzny w alumnacie był jednotraktowy, „z szeregowo ułożonymi pomieszczeniami,

${ }^{16}$ TG 72, s. 11-12; TG 278, s. 15.

${ }^{17}$ W. J a r m o li k, Znaczenie i funkcje Tykocina $w$ XVI-XVII w. Królewska historia miasta, „Białostocczyzna” 1991, R. VI, nr 3, s. 7. Vide: AGAD, Kapicjana, sygn. 36.

${ }^{18}$ Archiwum Narodowe w Krakowie, Oddział na Wawelu, Zbiór Zygmunta Glogera, sygn. 527, s. 5-6. Opis dworca starego z inwentarza z 1571 r. wydano drukiem w: J. M a r o s z e k, Pogranicze Litwy $i$ Korony w planach króla Zygmunta Augusta: z historii dziejów realizacji myśli monarszej między Niemnem a Narwia, Białystok 2000, s. 105.

${ }^{19}$ Inwentarze z 1698 i 1701 r.: „Alumnat przy moście nad Narwią, w kwadrat murowany”. AGAD, Archiwum Roskie, Akta Rodzinno-Majątkowe [dalej: ARos.], sygn. 411, s. 18; Biblioteka Jagiellońska [dalej: BJag.], rkps 6247, s. 17.

${ }^{20}$ AGAD, ARos., sygn. 411, s. 18; BJag., rkps 6247, s. 17.

${ }^{21}$ Inwentarze z 1698 i 1701 r.: „w trzecim [rogu - M.S.] kaplica”. Ibidem.

${ }^{22} \mathrm{~S}$. W i c h e r, op. cit., s. 20. 
a zespoły mieszkalne tworzyły dwie izby z sienią pośrodku"23. Wyjątkiem była środkowa część północnego skrzydła $\mathrm{z}$ dwoma kwadratowymi pomieszczeniami po prawej stronie sieni. Wjazd mieścił się w ściętym narożniku południowo-zachodnim. Po obu stronach sieni wjazdowej znajdowały się nieregularne trójkątne wnętrza. „Pomiędzy izbami mieszkalnymi ulokowano pomieszczenia kwadratowe dostępne z korytarzy prowadzących z dziedzińca wzdłuż osi przekątnych budynku" ${ }^{24}$. Pośrodku dziedzińca była studnia ${ }^{25}$.

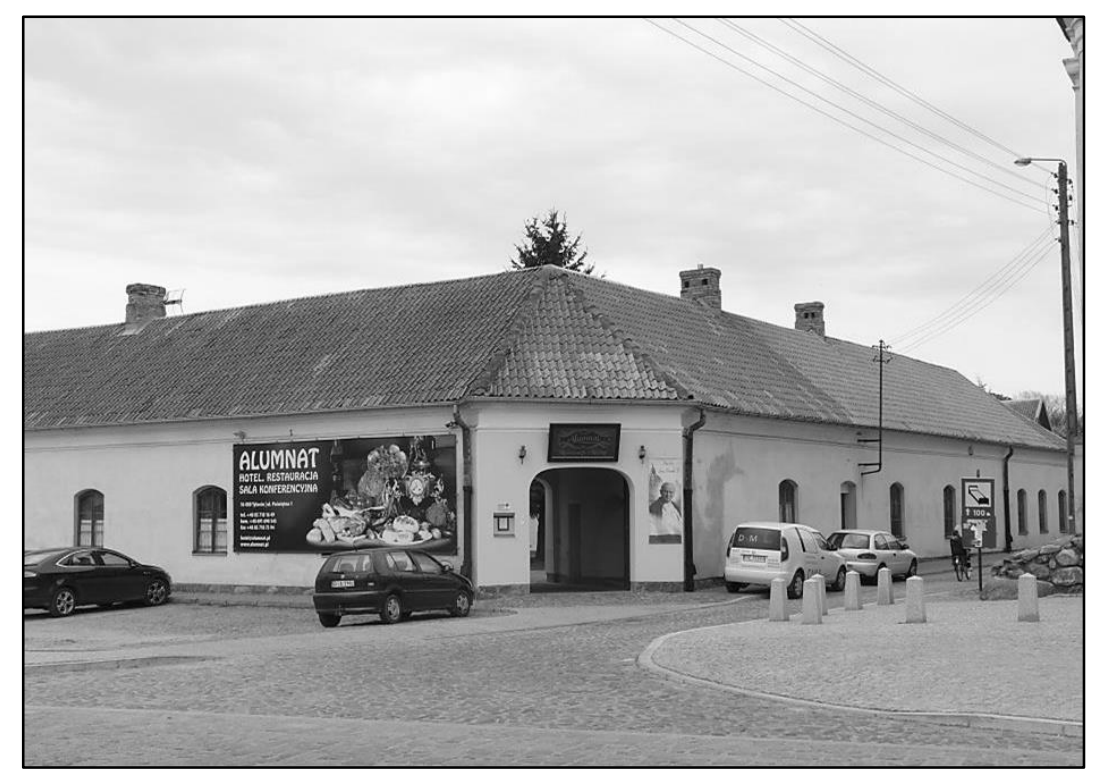

2. Alumnat od strony wjazdu w południowo-zachodnim narożniku budynku, fot. autor

Budynek był kilkukrotnie przebudowany i remontowany, przez co dziś wygląda nieco inaczej niż pierwotnie. Wpłynęła na to zwłaszcza przebudowa miasta przez Jana Klemensa Branickiego w XVIII w. Budynek stracił cechy obronności, przede wszystkim z powodu zburzenia baszt. Przejścia do nich zostały zamurowane. Branicki nadał alumnatowi późnobarokowy charakter wystroju i podwyższył dach o ok. 1,5 m. Utrzymał jednak pierwotny układ wnętrz ${ }^{26}$. Odnowił pomieszczenia i poddał szczególnej renowacji kaplicę alumnacką ${ }^{27}$. Podczas przebudowy

\footnotetext{
${ }^{23}$ Ibidem, s. 17.

${ }^{24}$ Ibidem, s. 18.

${ }^{25}$ P.M. G a rt ki e w i c z, Alumnat wojskowy w Tykocinie..., s. 127, 136-137; S. W i c h e r, op. cit., s. 15, 17-18, 20, 34 .

${ }^{26} \mathrm{~S} . \mathrm{W}$ i c h e r, op. cit., s. 34.

${ }^{27}$ Inwentarz z 1772 r.: „Odnowiony [alumnat - M.S.] z przymurowaniem wspaniałej kapliczki i innych wygód alumnackich". AGAD, ARos., sygn. 82, k. 292. Sebastian Wicher twierdzi, że
} 
usunięto tablicę fundacyjną, wykonano nowe sklepienia, przemurowano otwory okienne i drzwiowe, z elewacji zaś usunięto detal, pozostawiając jedynie ozdobny gzyms. Zmodernizowano także system ogrzewania budynku ${ }^{28}$. W XX w. doszło do kolejnych przebudów i renowacji, przez co dzisiejszy alumnat wygląda inaczej niż w XVII w. W zasadzie z tego okresu pozostały jedynie ,tylko poprzeczne i podłużne mury nośne" ${ }^{29}$. Z pierwotnego wyposażenia nie zachowały się żadne elementy, tzn. piece, posadzki, parapety itd. Dziś alumnat pełni funkcję hotelu i restauracji.

Fundacja Krzysztofa Wiesiołowskiego egzystowała najprawdopodobniej bez większych problemów aż do $1654 \mathrm{rr}^{30} \mathrm{~W}$ tym roku Kazimierz Kotowski z wojskiem najechał alumnat i pobił mieszkających tam weteranów ${ }^{31}$. Jednak gorsze czasy dla przytułku przyniosła wojna Rzeczypospolitej ze Szwecją. Budynek odgrywający dotąd pozytywną rolę społeczną, został wykorzystany do prowadzenia działań wojennych. Dnia 26 września 1655 r. Tomasz Szczawiński, dowodzący częścią pospolitego ruszenia ziemi bielskiej, zajął zamek i miasto Tykocin. Zrobił to najprawdopodobniej na rozkaz Bogusława Radziwiłła, który kilkanaście dni później przybył tam ze swoim wojskiem. Tykocin podczas potopu szwedzkiego był trzykrotnie oblegany przez wojska litewsko-polskie. Za pierwszym razem pułk dowodzony przez Krzysztofa Sapiehę ok. 5 lutego 1656 r. zdobył miasto bez rozlewu krwi, gdyż będące tam oddziały po zmarłym Januszu Radziwille przeszły na jego stronę. Twierdzy jednak nie udało się zdobyć, gdyż 26 lutego 1656 r. przybyła odsiecz radziwiłłowska. Drugie oblężenie rozpoczęło się w maju 1656 r. Ponownie bez większych problemów wojska wierne Janowi Kazimierzowi zdobyły miasto i przystapiły do blokady twierdzy. Trwała ona do 14 lipca 1656 r., kiedy Bogusław Radziwiłł ponownie przybył z odsieczą ${ }^{32}$. Podczas tych dwóch oblężeń nie wiemy, co się działo z weteranami mieszkającymi $\mathrm{w}$ alumnacie i z samym budynkiem.

zapis z inwentarza z 1772 r. sugeruje, że kaplica została wzniesiona na nowo, co mogło się wiązać $\mathrm{z}$ przemurowaniem ścian budynku $\mathrm{w}$ jego wschodniej części. Według niego potwierdza to, że alumnat w pewien sposób ucierpiał w pożarze Tykocina z $1741 \mathrm{r}$. S. W i c h e r, op. cit., s. 42. Józef Maroszek zaś twierdzi, że kaplica została wyremontowana przed 1717 r. J. M a r o s z e k, Dzieje województwa podlaskiego do 1795 r., Białystok 2012, s. 320.

${ }^{28}$ P.M. Gartki e wi c z, Alumnat wojskowy w Tykocinie..., s. 127, 130; S. W i c h e r, op. cit., s. 21.

${ }^{29} \mathrm{~S} . \mathrm{W}$ i c h e r, op. cit., s. 33.

${ }^{30}$ Zdarzały się oczywiście kłótnie i swary między mieszkańcami alumnatu, a także z jego zarządcami. Vide: J. M a r o s z e k, Dzieje województwa podlaskiego..., s. 311-313, 320. Nie miało to jednak większego wpływu na działalność fundacji.

${ }^{31}$ Ibidem, s. 320.

${ }^{32}$ M. S i e r b a, Tykocin podczas ,potopu” szwedzkiego, [w:] Spes in virtute, salus in victoria, red. A. Gładysz, J. Gładysz i D. Lipska, Lublin-Zabrze 2014, s. 95-99. 
Pod koniec 1656 r. wojska radziwiłłowsko-szwedzkie poszerzyły zakres fortyfikacji w Tykocinie. Poza twierdzą ufortyfikowano alumnat, klasztor bernardyński na wyspie na Narwi między miastem a twierdzą i spichlerz leżący najprawdopodobniej na zachód od alumnatu ${ }^{33}$. W relacji zdobycia zamku tykocińskiego z 1657 r. podano, że alumnat „był w wałach i palisadzie tak obwarowany, że przystąpić nie było jako. Klasztor też Bernardyński w wale i palisadach rzeką naokoło osłoniono. Spichlerz najmocniej we wszystko był ufortyfikowany, szaniec osobno z boków miał. Kamienica zasobna w palisadach, mając szańce po rogach" ${ }^{34}$.

Ufortyfikowanie alumnatu i wykorzystanie go jako punktu strzegącego przeprawy było bardzo zmyślnym posunięciem strony szwedzkiej. Mocny punkt obronny, oparty na budynku alumnatu wyposażonego w dwie baszty, nie pozwalał na zaatakowanie twierdzy tykocińskiej położonej na wyspie na Narwi. Szwedzi stworzyli niezmiernie silny system obronny, w którym jego poszczególne elementy miały się wzajemnie wspierać ogniem. Takie koncepcje pojawiły się już podczas budowy twierdzy tykocińskiej za czasów Zygmunta Augusta, aczkolwiek nie zostały wtedy zrealizowane ${ }^{35}$. Pomysł zaś wykorzystali Szwedzi.

Trzecie, ostatnie oblężenie Tykocina rozpoczęło się 9 listopada 1656 r. Dnia 21 stycznia 1657 r. pod miasto dotarł Paweł Jan Sapieha z dużą częścią armii litewskiej. Po bezskutecznych próbach mediacji zarządzono szturm na pozycje radziwiłłowsko-szwedzkie rankiem 27 stycznia 1657 r. ${ }^{36}$ Plan zarysowany przez dowództwo polegał na jednoczesnym ataku na wszystkie cztery punkty oporu: twierdzę, spichlerz, klasztor i alumnat. Przez to każda z pozycji obronnych była skazana wyłącznie na siebie i nie mogła wspierać pozostałych. Z pomocą atakującym przyszła bardzo mroźna zima, która skuła lodem Narew, dzięki czemu można było zaatakować twierdzę i klasztor bez korzystania z przeprawy. Na alumnat nacierała grupa piechoty i czeladzi obozowej (ok. 600 osób) dowodzona przez Alberta Kossakowskiego. Był to też punkt, który najwcześniej się poddał, bo już po godzinie walki. Wszystkich obrońców wycięto, a część zdobywców ruszyła na twierdzę, która została w końcu zdobyta, tak jak pozostałe punkty oporu ${ }^{37}$.

${ }^{33}$ W. M a j e w s k i, Potop szwedzki (1655-1660), [w:] Z dziejów wojskowych ziem pótnocno-wschodniej Polski, cz. 1, red. Z. Kosztyła, Białystok 1986, s. 107; J. P ł o s i ń s k i, Potop szwedzki na Podlasiu, Zabrze 2006, s. 129.

${ }^{34}$ Relacja obrotów wojennych pod Tykocinem r. 1656, wyd. O. Laskowski, „Przegląd Historyczno-Wojskowy" 1938, t. X, s. 256.

${ }^{35}$ J. M a r o s z e k, Pogranicze Litwy..., s. 324.

${ }^{36}$ Relacja obrotów wojennych..., s. 256; J. J a r n u tow k i, Tykocin, Miasto dawnej ziemi bielskiej, „Biblioteka Warszawska” 1885, t. IV, s. 175-176; J. P $\nmid$ o s i ń s k i, op. cit., s. 126-129.

${ }^{37}$ Relacja obrotów..., s. 256-257. Więcej na temat zdobycia Tykocina: J.A. C h r a p o w i c k i, Diariusz, cz. 1, oprac. T. Wasilewski, Warszawa 1978, s. 112; W. M a je w sk i, op. cit., s. 107-108; J. P ło s i ń s k i, op. cit., s. 131-134; M. S i e r b a, op. cit., s. 101-106. 
W lipcu 1657 r. Tykocin zajęly jeszcze wojska brandenburskie, aczkolwiek nie mamy informacji, by uczyniły jakiekolwiek szkody w alumnacie ${ }^{38}$. Także podczas najazdu kniazia Iwana Chowańskiego w 1660 r. przytułek dla weteranów nie ucierpiał, zniszczono zaś konwent bernardyński i kościół parafialny ${ }^{39}$.

Działania wojenne doprowadziły do zniszczenia alumnatu, aczkolwiek nie wiemy w jak dużym stopniu, gdyż nie mamy na ten temat źródeł. Należy jednak podejrzewać, że nie były one na tyle poważne, by znajdujące się tam mieszkania nie były atrakcyjne dla miejscowej ludności. Wręcz przeciwnie. Według rejestru pogłównego generalnego z $1662 \mathrm{r}$. mieszkało tam najprawdopodobniej 75 osób plebejskiego pochodzenia i być może niewymienieni w spisie podatkowym weterani w liczbie $12^{40}$. Było to oczywiście podyktowane zniszczeniami zabudowy miejskiej i powolną odbudową. W spisie pogłównego z $1673 \mathrm{r}$. wspomniano, że oprócz weteranów w alumnacie mieszkało 17 plebejów $^{41}$. W rejestrze o rok późniejszym zapisano informację o mieszkańcach alumnatu: „oprócz żołnierzy pokaleczonych plebejów 14"42.

Po potopie szwedzkim zmienił się zarząd alumnatu. W $1661 \mathrm{r}$. sejm zatwierdził nadanie na własność dziedziczną starostwa tykocińskiego z dobrami Dolistowo Stefanowi Czarnieckiemu ${ }^{43}$. W związku z tym źródło finansowania przytułku wojskowego przeszło $\mathrm{w}$ ręce prywatne $\mathrm{i}$ to od właściciela zależał zarząd nad obiektem. Nowemu właścicielowi Tykocina zalecono jedynie, by uszanował zasady fundacji Krzysztofa Wiesiołowskiego. Zmiana statusu własnościowego miała swoje konsekwencje, gdyż spadkobiercy Czarnieckiego wypłacali pieniądze na utrzymanie weteranom głównie ze względu na presję społeczną ${ }^{44}$. Braniccy nie dbali zbytnio o alumnat, co poświadcza skarga z czerwca 1675 r. na Katarzynę $\mathrm{z}$ Czarnieckich Branicką o niewypłacenie inwalidom z alumnatu raty kwartalnej ${ }^{45}$.

${ }^{38}$ S. A u g u s i e w i c z, Działania wojsk brandenburskich na pótnocno-wschodnim Mazowszu i Podlasiu wiosna i latem 1657 r., „Studia i Materiały do Historii Wojskowości” 2007, t. XLIII, s. $79,82-83,85$.

${ }^{39}$ J.A. C h r a p o w i c k i, op. cit., s. 253; A. K o c h a ń s k i, 526 lat dziejów miasta Tykocina na tle historii Polski, Białystok 2010, s. 238-239, 466-468; K. K o s s a r z e c k i, Kampania roku 1660 na Litwie, Zabrze 2005, s. 96-99, 122, 144; W. M u r a w i e c, Tykocin, [w:] Klasztory bernardyńskie w Polsce w jej granicach historycznych, red. H. Wyczawski, Kalwaria Zebrzydowska 1985, s. 393.

${ }^{40}$ AGAD, ASK, oddział I, sygn. 70, k. 685. Dokładne wyliczenia, metody obliczeń i ich wyniki dla rejestrów podatkowych z lat 1662-1675: M. S i e r b a, Kryzys miasta Tykocina po „potopie” szwedzkim i najeździe kniazia Chowańskiego, referat wygłoszony na konferencji Kryzys historii, historia w kryzysie (Łódź, 18-20 XI 2011), mps w posiadaniu autora.

${ }^{41}$ AGAD, ASK, oddział I, sygn. 70, k. 807.

${ }^{42}$ Ibidem, k. 845, 939.

${ }^{43}$ Biblioteka Czartoryskich, dokumenty pergaminowe, sygn. 1185.

${ }^{44}$ P.M. G a r t k i e w i c z, Tykocin..., s. 12.

${ }^{45}$ AGAD, Kapicjana, sygn. 42, s. 14-15. 
Mimo to alumnat trwał i spełniał swoją funkcję, na co wskazują wynotowani ze źródeł przez Józefa Maroszka mieszkańcy przytułku z lat $1660-1796^{46}$. Zaniedbania nowych właścicieli doprowadziły do stopniowego niszczenia budynku, który wymagał remontów. W inwentarzu z 1698 r. zapisano: „Dach poprawy potrzebujący, przez który bardzo zakapuje, z czego się sklepienia w celach psują... Okna naprawy także i piece potrzebują, mury od ulicy, a najbardziej bakszty obie od ziemi ratunku potrzebują"47.

Alumnat służył nie tylko jako miejsce zamieszkania dla weteranów i nielicznych plebejów. Po 1660 r. odegrał także inną, dość istotną rolę społeczną - był miejscem kultu religijnego. Podczas potopu Szwedzi zniszczyli murowany kościół rzymskokatolicki. Na jego miejsce powstał inny drewniany. Nie postał on długo, gdyż podczas najazdu wojsk moskiewskich w 1660 r. został spalony. Z wizytacji parafii tykocińskiej z 1680 r. dowiadujemy się, że „kościół parafialny przez napad moskiewski spalony. Nabożeństwa i msze odprawiają się w szpitalu, czyli alumnacie murowanym w kaplicy" ${ }^{\text {"48 }}$. Do kaplicy, mieszczącej się w absydzie alumnackiej, przeniesiono część sprzętów liturgicznych i obrazy, które udało się uratować przed zniszczeniem ${ }^{49}$. Wcześniej kaplica w absydzie alumnackiej służyła jedynie weteranom, gdyż nie sądzę, by ludność Tykocina chodziła tam na msze, mogąc uczęszczać do kościoła farnego. Przy kaplicy rezydował kapelan, opłacany przez weteranów ${ }^{50}$. Pod nią znajdowała się krypta, w której chowano niektórych z mieszkańców przytułku ${ }^{51}$.

Podsumowując, alumnat ufundowany przez Krzysztofa Wiesiołowskiego spełniał dwie-trzy funkcje w XVII w., na co miały wpływ wydarzenia, które zaszły podczas tego stulecia. Podstawowym celem, dla którego ta instytucja została powołana, był cel społeczny, czyli chęć niesienia pomocy weteranom wojskowym, którzy nie byli w stanie sami zapewnić sobie utrzymania. Funkcję tę alumnat pełnił od momentu powstania przez resztę wieku XVII, z wyjątkiem okresu potopu szwedzkiego. Po wojnie Rzeczypospolitej ze Szwecją przytułek żołnierski był także tymczasowym miejscem zamieszkania dla ludzi, którzy utracili swoje domostwa podczas konfliktu. W czasie wojny alumnat wykorzystano do celów militarnych. Konstrukcja i usytuowanie budynku pozwoliły stworzyć tam mocny punkt oporu broniący przeprawy na Narwi. Alumnat wchodził w skład silnej linii obrony szwedzkiej, która po ciężkiej walce uległa przeważa-

${ }^{46}$ J. M a ro s z e k, Dzieje województwa podlaskiego..., s. 314-319; i d e m, W. N a g ó r s k i, Tykocin. Miasto królewskie, Tykocin 2004, s. 68; J. M a r o s z e k, Znaczenie i funkcje Tykocina w XVII-XVIII w. Magnacka historia miasta, „Białostocczyzna” 1991, R. VI, nr 4, s. 5.

${ }^{47}$ AGAD, ARos., Akta Rodzinno-Majątkowe, sygn. 411, s. 18.

${ }^{48}$ Cyt. za: A. K o c h a ń s k i, op. cit., s. 466.

${ }^{49}$ Ibidem, s. 239.

${ }^{50}$ J. M a r o s z e k, Dzieje województwa podlaskiego..., s. 320.

${ }^{51}$ P.M. G a r t k i e w i c z, Tykocin..., s. 10. 
jącym siłom polsko-litewskim dopiero 27 stycznia 1657 r. Trzecią funkcją była funkcja religijna, którą niespodziewanie pełnił alumnat po spaleniu kościoła farnego przez Moskali w $1660 \mathrm{r}$.

\author{
Michat SIERBA
}

\title{
Tykocin's almshouse for veterans in $17^{\text {th }}$ century - social and military functions
}

The article describes seventeenth century history of one of the buildings in Tykocin - alumnat. It is the traditional name of an old almshouse for veterans, which was founded by Christopher Wiesiołowski in year 1633. It is a four-wing building with an internal courtyard. In the southeastern corner of the alumnat there is a half-round apse. Two towers were the defensive advantage of the building.

In the $17^{\text {th }}$ century the alumnat held several functions. It was founded as a charitable institution for 12 noble war veterans, who were wounded defending Polish-Lithuanian Commonwealth, or were unable to earn for living due to their old age. Because of its defensive qualities and being located in the nearness of the bridge on the Narew River, the alumnat was used as one of defending points during Polish-Swedish war, called "the flood". At that time the alumnat was obstructing access to the Tykocin fortress. After the war the alumnat became a temporary shelter not only for veterans, but also for people who had lost their homes during the war. In alumnatic apse there was a Roman Catholic chapel. In year 1660 the Tykocin's church was destroyed in a fire. After this incident the chapel in alumnat was used as a temporary church for Tykocin's community. 